\title{
Teresa Noll Trindade, Documentário e mercado no Brasil: da produção à sala de cinema
}

André Gatti*

Trindade, T. N. (2015). Documentário e Mercado no Brasil: da produção à sala de cinema. São Paulo: Alameda. ISBN: 978-85-7939-305-1

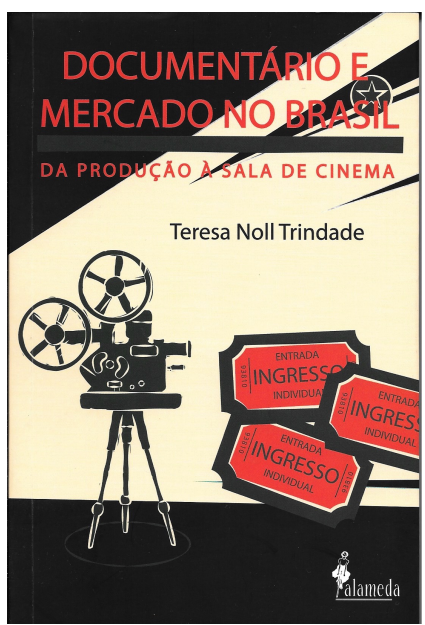

Recém publicado pela jovem pesquisadora Teresa Noll Trindade, a obra em tela é, na realidade, fruto de seu mestrado acadêmico realizado no âmbito do Programa de Pós-Graduação em Multimeios do Instituto de Artes da Universidade Estadual de Campinas-Unicamp. Nas suas 264 páginas, a autora se presta ao desafio de entender como o filme documentário brasileiro contemporâneo enfrenta o mercado de salas de cinema no nosso território.

Por sua vez, o enfrentamento da produção local com o mercado não se trata de algo necessariamente novo na história do cinema brasileiro, de um modo geral, tanto em relação ao filme de ficção quanto ao filme documentário propriamente dito. Afinal, sob o ponto de vista econômico, o espaço mercadológico do cinema no país sempre esteve ocupado pela produção estrangeira. A cinematografia do ocupante, principalmente, através dos seus filmes de ficção, formaram a mentalidade do público frequentador bem como estruturaram

* Fundação Armando Álvares Penteado - FAAP, Faculdade de Comunicação, Dept. de Cinema. 01242-902, São Paulo, Brasil. E-mail: apgatti@gmail.com 
a lógica do mercado das salas de cinema. No entanto, foi este ambiente adverso que permitiu o surgimento das primitivas e famosas cavações, pois as produções que enfocavam assuntos diversos e temas locais jamais interessaram as produtoras/distribuidoras internacionais que aqui operam há mais de cem anos. Dessa maneira, o filme documentário se desenvolveu como a mais densa produção audiovisual brasileira.

Entretanto, nos tempos mais recentes, pode-se afirmar que o filme documentário brasileiro escapou dos grilhões da cavação clássica e tornou-se uma expressão cinematográfica autônoma. Esta foi estimulada, basicamente, por dois fatores: tecnologias digitais e ambiente legislativo incentivador da produção fílmica independente. A tecnologia digital barateou e facilitou o acesso aos meios de produção audiovisual criando uma nova vaga do gênero no Brasil; enquanto que o regime estatal de incentivos possibilitou o acesso a recursos financeiros nunca antes vistos para este tipo de expressão. É neste novo contexto que a autora irá desenvolver a sua inédita pesquisa.

O período histórico abordado pelo trabalho (2000 a 2009) já nos dá uma visão de conjunto do sistema de produção; sistema este que prevalece até o presente momento ainda que nele tenham se inserido novos componentes, como a promulgação da chamada Lei do Cabo. Em seu levantamento, a autora alcança seus objetivos ao identificar os realizadores, os subgênero, o volume de filmes realizados e a expressão numérica (público e bilheteria) que as obras atingiram por ocasião de suas exibições nas salas de cinema brasileiras. Utilizando-se de matrizes analíticas acadêmicas, de fontes primárias diversas (Ancine, Filme B etc.) e de uma abordagem rigorosa e original ao mesmo tempo, Noll Trindade conseguiu construir um panorama realista do estágio em que se encontra o filme documentário brasileiro contemporâneo.

$\mathrm{O}$ texto é fartamente permeado por um expressivo número de gráficos e quadros que ilustram, numérica e visualmente, o desempenho que os filmes documentários obtiveram nos cinemas. Vou destacar algumas referências que me chamaram a atenção de forma mais contundente. Dentre estas encontramos, por exemplo, aquela que se refere à exibição desse tipo de filme que, via de regra, tendeu a ficar restrita às chamadas salas de arte. Esta situação vai ser definidora de praticamente tudo aquilo que acontece no percurso econômicofinanceiro das obras.

O problema é que tal tipo de sala representava apenas $10 \%$ dos cinemas brasileiros em atividade no período estudado pela autora. Logo, o que se pode deduzir desse fato é que o mercado cinematográfico enxerga o documentário como um filme de nicho o que, em parte, explicaria o seu modesto desempenho comercial. Isso porque, nas circunstâncias em que a máquina de produção 
e comercialização do cinema brasileiro funciona hoje, esse reduzido espaço de exibição não é suficiente para atender à demanda, o que tende a acirrar a competição e, consequentemente, inflaciona o número de obras lançadas comercialmente e que buscam um lócus que lhes permita visibilidade. Ademais, existe um fator preponderante nesse mecanismo: muitos filmes são produzidos com recursos da Lei do Audiovisual e ela exige que os filmes aquinhoados sejam prioritariamente exibidos nas salas de cinema. Portanto, de uma maneira indireta por assim dizer, a Lei do Audiovisual criou uma espécie de anomalia mercadológica, já que o mercado de exibição cinematográfica é, desde o início do século XX, pautado pela comercialização de filmes de ficção, fato que permanece até os dias de hoje. Por sua vez, sabe-se que, economicamente, o filme documentário de longa-metragem se consagrou como um produto destinado à exibição em circuito televisivo e não ao circuito das salas escuras.

Observa-se, ainda, o fato de que o número de filmes documentários presentes nestas últimas gira em torno de $30 \%$ dos títulos totais lançados no mercado. Via de regra, o documentário se caracteriza por ser um gênero cuja produção tem baixo valor agregado. Portanto, a sua exposição no circuito comercial tende a ser bastante tímida, o que poderá ser sentido diretamente no desempenho que tais filmes obtém, em média, por ocasião de sua exibição nos cinemas. Claramente, isto pode ser visto, por exemplo, nos Gráficos 2 e 3, às páginas 60 e 61 respectivamente. O Gráfico 2 apresenta o número de ingressos alcançado no período em que percebe-se um claro avanço, notadamente a partir do ano de 2002. Ainda que a curva de desempenho seja bastante oscilante, ela teve o seu ápice no citado ano, quando foram vendidos 496.238 ingressos. O Gráfico 3 apresenta a média de público alcançada pelos títulos lançados, e não por acaso 2002 contém também as maiores médias. O que esses gráficos traduzem? Duas coisas: trata-se de um mercado estagnado, pois não foi capaz de superar a faixa de meio milhão de ingressos; por outro lado, esta faixa está sendo canibalizada pelo aumento expressivo dos títulos em lançamento, de um modo geral, que tem crescido regularmente nos últimos anos. Isso traz como consequência a inevitável diminuição média de entradas por filme.

O texto de Noll Trindade tem vários méritos, um deles é o de explorar uma vertente da indústria cinematográfica brasileira em que a bibliografia ainda é bastante tímida, nomeadamente quando se tem em vista o volume de produção de filmes documentários no atual cenário nacional. Portanto, seu livro vem prestar uma ajuda inestimável à constituição de uma musculatura mais sólida a esse segmento de nosso universo audiovisual. Outra de suas grandes qualidades é a de lançar luzes fortes sobre um assunto algo obscuro e que, até agora, só emitia algum brilho em matérias dispersas, sem que estas viessem a cons- 
tituir uma unidade de pensamento analítico. Nesse sentido, consideramos que "Documentário e mercado no Brasil: da produção à sala de cinema" se traduz numa obra incontornável para todos aqueles que se interessam, de uma forma ou de outra, pelo filme documentário. 